\title{
A Gift from a Founder Member
}

THE generosity of a Founder Member of The Business Historical Society, Mr. N. Penrose Hallowell, who has contributed the sum of $\$ 1,000$ to the Society, has resulted in the acquisition of a large collection of miscellaneous books, pamphlets, pictures, broadsides,

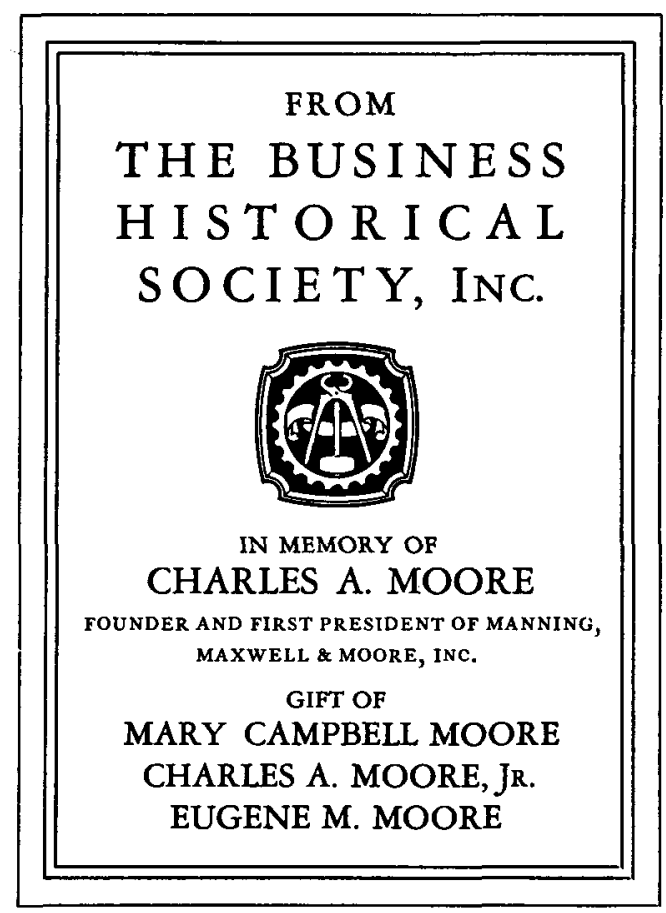

Sample Bookplate used in the Fifty Thousand Volumes of the C. A. Moore Memorial Collection

maps, and manuscript from Rutland, Vermont. The nucleus of the collection was formerly the property of Ex-Governor John Boardman Page, who was president of the Rutland Railroad Company at its organization in $\mathrm{I} 867$, and who was also president (1873-81) of the Continental Railway and Trust Company, organized to build the New York, West Shore, and Chicago Railway 
(afterwards known as the West Shore Railroad), and a director of the Champlain Transportation Company.

There were approximately I,000 bound books and 2,000 pamphlets, 500 broadsides, pictures, and documents. The books consisted of magazines, annuals and monographs, state reports, and railroad guides. The pamphlets consisted of annual reports, acts of incorporation, memorials, and other documents, mostly relating to railroads and canals, but including many interesting examples of pamphlet contributions to American economic history. There were also a great many early insurance reports and an unusual collection of documents relating to the Hoosac Tunnel. There was a considerable collection of pictures, photographs, drawings, and water colors, both framed and unframed, of early locomotives, and other railroad scenes.

The collection included a copy of the first marine newspaper, published on the steamship Great Eastern while it was laying the first Atlantic cable. Another interesting item was a profile map showing the stages of development of a section of a transcontinental railroad. There was a rare historical review of the New York and Erie Railroad by Eleazar Lord, New York, I 855, bound in quarter morocco; and Facts and Observations in Relation to the Origin and Completion of the Erie Canal, New York, 1825. Among the magazines there was an interesting run of the Annual Register (or a View of the History, Politics and Literature for the Year), vols. I to 59,1758 to I8I7; and the Gentleman's Magazine (not complete) from 1759 to I 820 . Among the modern magazines were included sets of Gunton's Magazine, The Electrical World, Engineering Record, Engineering Magazine, etc.

The most valuable part of the collection was in the railroad items, particularly the early pamphlets pertaining to the transcontinental routes. There were many waifs and strays and ephemeral matters which are so hard to find, but which throw side-lights on the history of transportation.

Perhaps the most curious item was "Het Groote Tafereel der Dwaasheid" (The Great Picture of Foolishness), a collection of Dutch cartoons and satirical verses and articles, published in 1720 , on the downfall of the speculative craze that culminated in John Law's Mississippi Company on the Continent and in the South Sea Bubble in England. This attack on the eighteenth-century predecessors of our get-rich-quick schemes was quaintly stated on the title-page to be "Printed as a Warning for Posterity, in the 


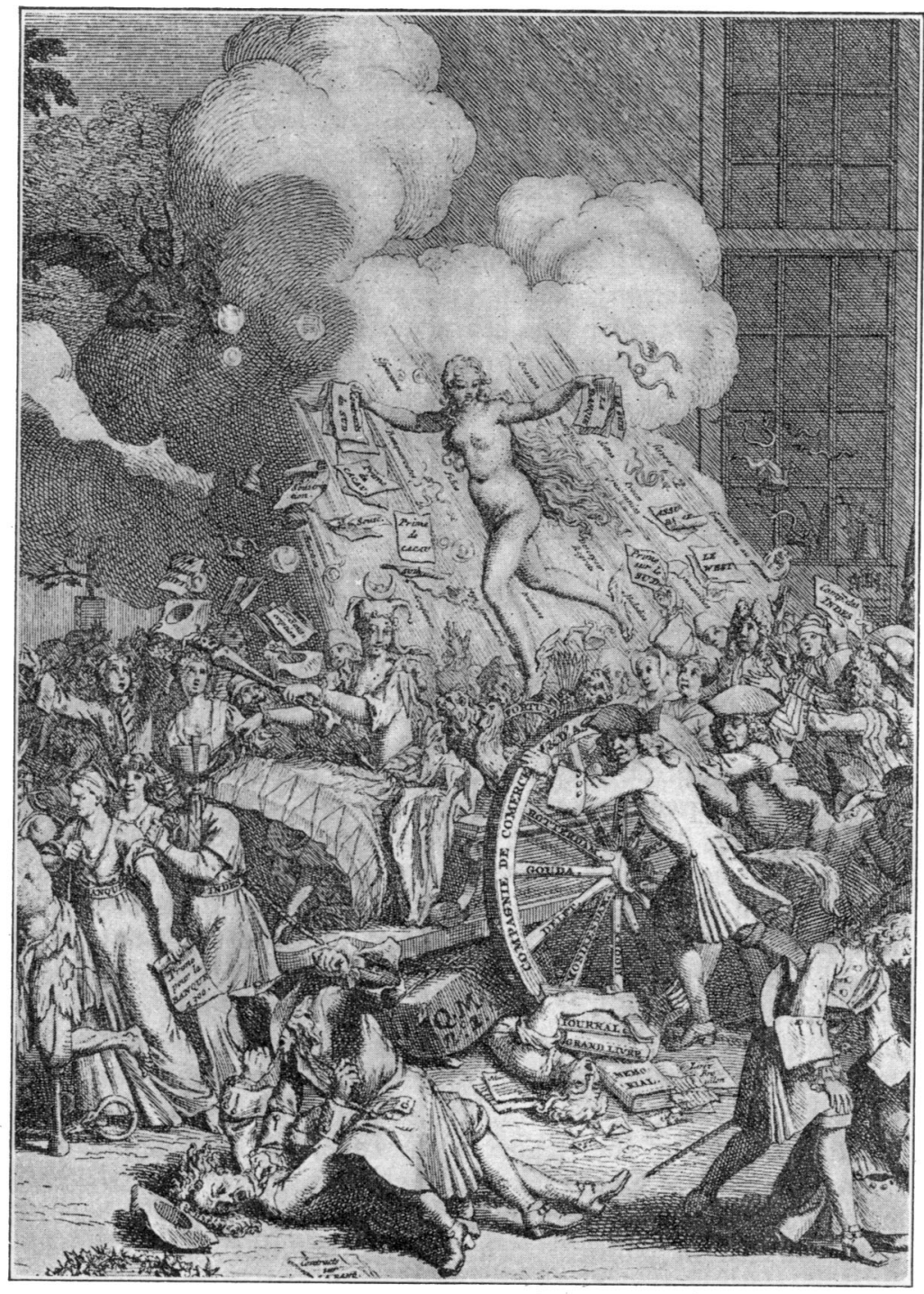

THE GREAT PICTURE OF FOOLISHNESS (1720)

John Law helping Dame Fortune to shower her gifts over all mankind. The title page of this book says that it was "printed as a warning for posterity, in the fatal year of many follies among the wise -1720 " 
fatal year, of many Follies among the Wise, 1720." Here was described and pictured, in French, English, and Dutch by turns, John Law as Atlas supporting the world, as Don Quixote tilting at the wind-mills, as the "monopolist of wind." Several views of the Rue Quinquempoix were found (with a throng of Frenchmen even wilder than some curbstone real-estate exchange in the late Florida boom) dealing in the Mississippi Company's ventures. Two editions of the collection, differing in many details, were published in 1720. The Harvard College Library has one edition, and the Hallowell gift provides the Historical Society with the other.

\section{A Railroad Item}

A collection of early railroad history has been added to The Business Historical Society Collection. It covers the early history of the Delaware, Lackawanna, and Western Railroad Company. The fourth annual report contains a rare communication to the Evening Post of November 9, 1857, which brings up the history of the Cheever Controversy, in which some of the Wall Street Phelps family were interested.

The most interesting of the documents, however, is the History of the Recent Investigation into the Affairs of the D. L. \& W. R. R. Co., which "is designed to disabuse the minds of the stockholders, and, at the same time, to show the doubtful benefit, if not the positive evil, of such investigations and the unfairness of this one in particular." George D. Phelps of the Cheever Controversy episode seems to have been the storm centre. Mr. Phelps subjoins another document called "Confidential." There was a real fight on at this time, and in one instance the opposition apparently bribed some clerk to abstract from the files the confidential documents of the officers. Then follow other "confidential" items and another Review of the Report of the Investigating Committee.

In all there are nine separate documents, which cover the early history of this famous railroad thoroughly, with all the "dirty linen washed in public." Their value lies not only in possible analogies to present-day railroad history but in the methods of financing and the results of such financing. The result of this investigation was in many cases that perfectly innocent parties were injured, and it illustrated the principle of "The Forgotten Man" as expressed by the late William Graham Sumner. 